\title{
Impact of mastery cooperative learning strategy and individual inquiry on attaining the technical aspects of the stages of shot put and digital achievement using the linear method among the students of the University of Jordan
}

\author{
WALID HAMMOURI ${ }^{1}$, KHITAM AY ${ }^{2}$, MOHAMMAD AL-DABABSEH ${ }^{3}$ \\ ${ }^{1,2,3}$ Department of Supervision and Education, University of Jordan, JORDAN
}

Published online: March 25, 2016

(Accepted for publication February 05, 2016)

DOI:10.7752/jpes.2016.01009

\begin{abstract}
:
Physiological indicators say a lot about the preparedness and performance of athletes. We considered the This study investigates the Impact of mastery cooperative learning strategy and individual inquiry in using the linear method among female students of the university of Jordan,the study sample consisted of (42) female students enrolled in track and field course (1) at the Faculty of physical education at the university of Jordan during the first quarter 2014/2015. The sample was divided into three equal groups. The first group $(n=14)$ taught using the mastery cooperative learning strategy, the second group $(n=14)$ taught using the individual inquiry strategy, while the third group $(n=14)$ was taught using the traditional method. Results showed that there were statistical differences in favor of the mastery cooperative learning strategy and individual inquiry strategy over the traditional way.

Key words: mastery learning, individual inquiry, shot put, linear way, The University of Jordan
\end{abstract}

\section{Introduction}

Strategies and teaching methods have evolved as a result of the inevitable evolution of contemporary democratic societies based on modern educational psychology and educational research that took on the increase, because of the awareness of teachers and their need to change the traditional teaching methods in the education process (Mosston \& Ashworth,1986). And the creation of modern teaching strategies to help students achieve their objectives through the creation of methods of teaching alternative consistent with the scientific development and technological progress, which has made the world a small village; which worked to increase the acceleration of knowledge transmission rapidly surpassing distances and overcome as soon as possible and with less effort than the global openness easy and follow-up all new and sophisticated (Al-Samady, 2007)

The Mastery Cooperative learning And what accompanying of sequential procedural steps and Organized to prepares the students for individual work and the division of students into heterogeneous groups to work together using dialogue and discussion and exchange of information and classification and interpretation and analysis, and evaluate and make comparisons and draw conclusions and generate ideas and guidance from the teacher; important in highlighting the role of student and refine her personality and the ability to cooperate and communicate with others and acceptance and access for students to the point of perfection in the acquisition of skills and motor abilities ( Salavin, 2005)

Many researchers agree that cooperative learning has many benefits that distinguish it from the rest of the strategies through the development of the capacity of students to creative thinking and thinking skills over knowledge and capabilities of different thinking and take advantage of learners from each other's experiences and improve learners' attitudes towards themselves and others and curriculum, teacher and educational institution, Carol suggested a model for mastery of learning which is based on three concepts. (Ba,ajawi,2006)

1-The concept of educational mission( Learning Task) associated with the success of the learner in the amount of time it takes to learn that task, or how much they actually takes the learner to learn and interact with the task.

2- The ability to understand(Understanding),it means learner's ability to absorb and understand the nature of the educational mission and understand it,and try to decode and analyze their symbols and try to integrate them in the proceeds of knowledge in order to Mastery

3- The quality of teaching (instructional Qualities), this concept confirms to follow a variety methods of teaching to provide content to suit the majority of students, from these methods that have extreme importance in Carol model for Mastery learning is cooperative learning method.

The mastery learning from the teaching strategies, which must be arranged and sequenced on the pyramid, to be taught segmented into clear phases of learning in an educational skills or more than, then testing students after they finished, if they not reach to the Mastering, they must providing additional time to perform 
Mastering in testing, and control of the main phases of skill before moving on to the other skills(Mosston \& Ashworth,1986).

As for the strategy of directed individual inquiry, it is a way to search and investigate individually that means every individual looking for the answer to a specific question and research and investigation to find the best ways and the shortest to explore the situation or a problem concern to all students, then determined this situation and the problem and the questions that will discuss for an answer to it, then everybody is integrated in the activity that is being sought during the discussion of the results that have been reached between the students them self, and the teacher on the other hand. (Al-Hilah, 1999).

This study investigates the impact of mastery cooperative learning strategy and individual inquiry in attaining the technical aspects of the stages of the shot put and digital achievement using the linear method among students of the university of Jordan, the survey is the more modern teaching strategies effective in the development of scientific thinking among students, as it provides an opportunity for students to practice teaching methods, and the practice of the survey on their own skill, so the student will think and search for the result of her teaching, the survey strategy depend on a set of procedures adopt on the basis of confrontation the problems of the student to give him opportunity to create independent thinking, and require carrying out design method for consideration in order to reach to resolution and implementation, the student collect data and organize it, then reach to conclusions under the supervision of teacher.

\section{Method}

\section{Participates and procedure}

This study investigates the Impact of mastery cooperative learning strategy and individual inquiry in using the linear method among students of the university of Jordan, the study sample consisted of (42) under graduate female students who were physical education college at the university of Jordan. ( $M$ age $=19.4 \mathrm{sd}$ $=1.35$ ). All the subjects were enrolled in track and field course (1), they were divided deliberate into three groups, the first group $(n=14)$ taught by mastery cooperative learning strategy, the second group $(n=14)$ have been using their individual oriented inquiry in teaching, while the third group $(n=14)$ taught by the traditional way in teaching, Permission to conduct this study was received from the study sample and head dean of faculty of physical education at the university of Jordan. The students were told the purpose of the study and their rights as participants and they were asked to sign a consent form. The evaluation test of technical phases of the shot put skill was designed by the researchers after consulting scientific references of track and field federation and international coaches, the researchers designed an educational program based on the mastery cooperative learning strategy and another one based on individual- oriented in order to improve the performance of the shot put skill for the study sample, pre-test was measured to the three study samples for the variables of this study .the variables included the stages of the shot put and digital achievement after a warm-up ,the researchers recording the best of three tries, according to international law to the shot put using the legal tools approved by the International Association of track and field.. After applied the two months educational program which contained (16) units, twice units a week each unit was (75) minutes of training, the post-test were taken, The statistical processing included arithmetic mean, standard deviation, Analysis of variance, REGW comparisons Posterior.

\section{Results}

Table1. The average and standard deviation for the applied skills of shot-putting and its pre and post distances for the three groups

\begin{tabular}{|c|c|c|c|c|c|}
\hline \multirow{2}{*}{ Skill parts } & \multirow{2}{*}{ Group } & \multicolumn{2}{|c|}{ Pre measurement } & \multicolumn{2}{|c|}{ Post measurement } \\
\hline & & Average & Deviation & average & Deviation \\
\hline \multirow{3}{*}{ Preparation } & Traditional & 2.26 & 0.54 & 2.90 & 0.33 \\
\hline & Perfected cooperative & 2.33 & 0.76 & 8.20 & 0.75 \\
\hline & Oriented survey & 2.70 & 0.58 & 8.61 & 0.89 \\
\hline \multirow{3}{*}{ Crawling } & Traditional & 2.24 & 0.37 & 2.86 & 0.20 \\
\hline & Perfected cooperative & 2.16 & 0.45 & 7.79 & 1.01 \\
\hline & Oriented survey & 2.26 & 0.74 & 7.93 & 0.89 \\
\hline \multirow{3}{*}{ Power situation } & Traditional & 2.27 & 0.62 & 2.89 & 0.40 \\
\hline & Perfected cooperative & 1.89 & 0.66 & 7.71 & 0.98 \\
\hline & Oriented survey & 2.36 & 0.60 & 8.00 & 0.87 \\
\hline \multirow{3}{*}{$\begin{array}{l}\text { Basic } \\
\text { accelerating } \\
\text { situation }\end{array}$} & Traditional & 2.21 & 0.52 & 2.91 & 0.32 \\
\hline & Perfected cooperative & 2.03 & 0.50 & 7.96 & 0.88 \\
\hline & Oriented survey & 2.40 & 0.48 & 8.29 & 1.00 \\
\hline \multirow{3}{*}{$\begin{array}{l}\text { Hand motion } \\
\text { situation }\end{array}$} & Traditional & 2.41 & 0.41 & 2.97 & 0.22 \\
\hline & Perfected cooperative & 2.36 & 0.57 & 8.33 & 1.08 \\
\hline & Oriented survey & 2.71 & 0.58 & 8.69 & 1.07 \\
\hline \multirow[t]{2}{*}{ Covering } & Traditional & 2.61 & 0.29 & 3.06 & 017 \\
\hline & Perfected cooperative & 2.76 & 0.28 & 8.07 & 1.28 \\
\hline
\end{tabular}


WALID HAMMOURI, KHITAM AY, MOHAMMAD AL-DABABSEH

\begin{tabular}{clllll}
\hline & Oriented survey & 2.74 & 0.38 & 8.44 & 0.65 \\
Distance of & Traditional & 5.28 & 0.29 & 6.06 & 0.31 \\
Shot- put & Perfected cooperative & 5.63 & 0.42 & 7.13 & 0.30 \\
& Oriented survey & 5.49 & 0.48 & 7.40 & 0.62 \\
\hline
\end{tabular}

Table 2. The average, standard deviation and the calculated $(\mathrm{t})$ value between the pre and post measurements for the perfected cooperative strategy group

\begin{tabular}{|c|c|c|c|c|c|}
\hline Skill Parts & Measurements & Average & $\begin{array}{l}\text { Standard } \\
\text { deviation }\end{array}$ & $\mathrm{T}$ value & $\begin{array}{l}\text { Level of } \\
\text { significance }\end{array}$ \\
\hline \multirow{2}{*}{ Preparation } & Pre & 2.33 & 0.76 & \multirow{2}{*}{25.29} & \multirow{2}{*}{$* 0.000$} \\
\hline & Post & 8.20 & 0.75 & & \\
\hline \multirow{2}{*}{ Crawling } & Pre & 2.16 & 0.45 & \multirow{2}{*}{23.83} & \multirow{2}{*}{$* 0.000$} \\
\hline & Poet & 7.79 & 1.01 & & \\
\hline \multirow{2}{*}{ Power situation } & Pre & 1.89 & 0.66 & \multirow{2}{*}{17.70} & \multirow{2}{*}{$* 0.000$} \\
\hline & Post & 7.71 & 0.98 & & \\
\hline \multirow{2}{*}{$\begin{array}{l}\text { Basic } \\
\text { accelerating } \\
\text { situation }\end{array}$} & Pre & 2.03 & 0.50 & \multirow[b]{2}{*}{28.05} & \multirow[b]{2}{*}{$* 0.000$} \\
\hline & Post & 7.96 & 0.88 & & \\
\hline \multirow{2}{*}{$\begin{array}{l}\text { Hand motion } \\
\text { situation }\end{array}$} & Pre & 2.36 & 0.57 & \multirow{2}{*}{22.74} & \multirow{2}{*}{$* 0.000$} \\
\hline & Post & 8.33 & 1.08 & & \\
\hline \multirow{2}{*}{ Covering } & Pre & 2.76 & 0.28 & \multirow{2}{*}{15.72} & \multirow{2}{*}{$* 0.000$} \\
\hline & Post & 8.07 & 1.28 & & \\
\hline Distance of shot & Pre & 5.63 & 0.42 & \multirow{2}{*}{17.79} & \multirow{2}{*}{$* 0.000$} \\
\hline- put & Post & 7.13 & 0.30 & & \\
\hline
\end{tabular}

$\mathrm{T}$ value at $0.05=2.16$

Table (2) shows the average and the standard deviation and the calculated $(\mathrm{t})$ value between the pre and post measurements for the perfected cooperative learning students. $(\mathrm{t})$ value shows the difference for the static significant in the applied skills of shot-put and its distance, in which all the calculated $(t)$ value were higher than $2.16(\mathrm{~T} \square 2.16)$ for the level 0.05 , where these differences in favor to the post measurement.

Table 3. The average, standard deviation and the calculated $(\mathrm{t})$ value between the pre and post measurements for the traditional group

\begin{tabular}{|c|c|c|c|c|c|}
\hline Skill parts & Measurements & Average & $\begin{array}{l}\text { Standard } \\
\text { deviation }\end{array}$ & $\mathrm{T}$ value & $\begin{array}{l}\text { Level of } \\
\text { significance }\end{array}$ \\
\hline \multirow{2}{*}{ Preparation } & Pre & 2.26 & 0.54 & \multirow{2}{*}{10.12} & \multirow{2}{*}{$* 0.000$} \\
\hline & Post & 2.90 & 0.33 & & \\
\hline \multirow{2}{*}{ Crawling } & Pre & 2.24 & 0.37 & \multirow{2}{*}{11.52} & \multirow{2}{*}{$* 0.000$} \\
\hline & Post & 2.86 & 0.20 & & \\
\hline \multirow{2}{*}{ Power situation } & Pre & 2.27 & 0.62 & \multirow{2}{*}{9.17} & \multirow{2}{*}{$* 0.000$} \\
\hline & Post & 2.89 & 0.40 & & \\
\hline \multirow{2}{*}{$\begin{array}{l}\text { Basic accelerating } \\
\text { situation }\end{array}$} & Pre & 2.22 & 0.52 & \multirow{2}{*}{12.28} & \multirow{2}{*}{$* 0.000$} \\
\hline & Post & 2.91 & 0.32 & & \\
\hline \multirow{2}{*}{$\begin{array}{l}\text { Hand motion } \\
\text { situation }\end{array}$} & Pre & 2.41 & 0.41 & \multirow{2}{*}{9.29} & \multirow{2}{*}{$* 0.000$} \\
\hline & Post & 2.97 & 0.22 & & \\
\hline \multirow{2}{*}{ Covering } & Pre & 2.61 & 0.29 & \multirow{2}{*}{10.33} & \multirow{2}{*}{$* 0.000$} \\
\hline & Post & 3.06 & 0.17 & & \\
\hline \multirow{2}{*}{$\begin{array}{l}\text { Distance of shot- } \\
\text { put }\end{array}$} & Pre & 5.28 & 0.29 & \multirow{2}{*}{9.43} & \multirow{2}{*}{$* 0.000$} \\
\hline & Post & 6.06 & 0.31 & & \\
\hline
\end{tabular}

$\mathrm{T}$ value at $0.05=\overline{2.16}$

Table (3) shows the value average and standard deviation of the calculated (t)value between the pre and post measurements for the traditional learning group, the calculated $(\mathrm{t})$ value shows the difference for the static significant in the applied skills of shot- put as well as its distance, in which all the values were higher than 2.16 ( $\mathrm{T} \square 2.16$ ) for the level 0.05 , where these differences in favor to the pre measurement. 
Table 4. The average, standard deviation and) calculated ( $\mathrm{t}$ ) value between the pre and post measurements individual oriented survey group.

\begin{tabular}{|c|c|c|c|c|c|}
\hline Skill parts & measurements & Average & $\begin{array}{l}\text { Standard } \\
\text { deviation }\end{array}$ & $\mathrm{T}$ value & $\begin{array}{c}\text { Level of } \\
\text { significance }\end{array}$ \\
\hline \multirow{2}{*}{ Preparation } & Pre & 2.70 & 0.58 & \multirow{2}{*}{38.13} & \multirow{2}{*}{$* 0.000$} \\
\hline & Pos & 8.61 & 0.89 & & \\
\hline \multirow{2}{*}{ Crawling } & Pre & 2.26 & 0.74 & \multirow{2}{*}{30.90} & \multirow{2}{*}{$* 0.000$} \\
\hline & Post & 7.93 & 0.89 & & \\
\hline \multirow{2}{*}{ Power situation } & Pre & 2.36 & 0.60 & \multirow{2}{*}{36.03} & \multirow{2}{*}{$* 0.000$} \\
\hline & Post & 8.00 & 0.87 & & \\
\hline \multirow{2}{*}{$\begin{array}{l}\text { Basic } \\
\text { accelerating } \\
\text { situation }\end{array}$} & Pre & 2.40 & 0.48 & \multirow[b]{2}{*}{26.09} & \multirow[b]{2}{*}{$* 0.000$} \\
\hline & Post & 8.29 & 1.00 & & \\
\hline \multirow{2}{*}{$\begin{array}{l}\text { Hand motion } \\
\text { situation }\end{array}$} & Pre & 2.71 & 0.58 & \multirow{2}{*}{22.04} & \multirow{2}{*}{$* 0.000$} \\
\hline & Post & 8.69 & 1.07 & & \\
\hline \multirow{2}{*}{ Covering } & Pre & 2.74 & 0.38 & \multirow{2}{*}{30.44} & \multirow{2}{*}{$* 0.000$} \\
\hline & Post & 8.44 & 0.65 & & \\
\hline \multirow{2}{*}{$\begin{array}{l}\text { Distance of shot- } \\
\text { put }\end{array}$} & Pre & 5.49 & 0.48 & \multirow{2}{*}{10.65} & \multirow{2}{*}{$* 0.000$} \\
\hline & Post & 7.40 & 0.62 & & \\
\hline
\end{tabular}

$\mathrm{T}$ value at $0.05=2.16$

Table (4) shows the average and the standard deviation and the calculated ( $\mathrm{t}$ ) value between the pre and post measurements for the individual oriented survey group, the calculated $(t)$ value shows the difference for the static significant in the applied skills of shot-put as well as its distance were higher than 2.16 (T $\square 2.16)$ for the level 0.05 , where these differences in favor of the post measurement.

Table 5.Results for analyzing the contrast unilateral for the stages of shot-put skill and the throwing distance in the post measurement for the three groups

\begin{tabular}{|c|c|c|c|c|c|c|}
\hline Skill parts & $\begin{array}{l}\text { Contrast } \\
\text { Source }\end{array}$ & $\begin{array}{l}\text { Sum of } \\
\text { squares }\end{array}$ & $\begin{array}{l}\text { Degrees of } \\
\text { freedom }\end{array}$ & $\begin{array}{c}\text { Average } \\
\text { squares }\end{array}$ & $\mathrm{F}$ value & $\begin{array}{c}\text { Level of } \\
\text { significance }\end{array}$ \\
\hline \multirow{3}{*}{ preparation } & $\begin{array}{l}\text { Between } \\
\text { groups }\end{array}$ & 284.27 & 2 & 142.13 & \multirow{3}{*}{290.87} & \multirow{3}{*}{$* 0.000$} \\
\hline & In groups & 19.06 & 39 & 0.49 & & \\
\hline & Total & 303.33 & 41 & & & \\
\hline \multirow{3}{*}{ Crawling } & $\begin{array}{l}\text { Between } \\
\text { groups }\end{array}$ & 233.48 & 2 & 116.74 & \multirow{3}{*}{189.38} & \multirow{3}{*}{$* 0.000$} \\
\hline & In groups & 24.04 & 39 & 0.62 & & \\
\hline & Total & 257.52 & 41 & & & \\
\hline \multirow{3}{*}{ Power situation } & $\begin{array}{l}\text { Between } \\
\text { groups }\end{array}$ & 230.58 & 2 & 115.29 & \multirow{3}{*}{183.93} & \multirow{3}{*}{$* 0.000$} \\
\hline & In groups & 24.45 & 39 & 0.63 & & \\
\hline & Total & 255.03 & 41 & & & \\
\hline \multirow{3}{*}{$\begin{array}{l}\text { Basic } \\
\text { accelerating } \\
\text { situation }\end{array}$} & $\begin{array}{l}\text { Between } \\
\text { groups }\end{array}$ & 253.82 & 2 & 126.91 & \multirow{3}{*}{203.11} & \multirow{3}{*}{$* 0.000$} \\
\hline & In groups & 24.37 & 39 & 0.62 & & \\
\hline & Total & 278.19 & 41 & & & \\
\hline \multirow{3}{*}{$\begin{array}{l}\text { Hand motion } \\
\text { situation }\end{array}$} & $\begin{array}{l}\text { Between } \\
\text { groups }\end{array}$ & 286.90 & 2 & 143.45 & \multirow{3}{*}{182.03} & \multirow{3}{*}{$* 0.000$} \\
\hline & In groups & 30.73 & 39 & 0.79 & & \\
\hline & Total & 317.64 & 41 & & & \\
\hline \multirow{3}{*}{ Covering } & $\begin{array}{l}\text { Between } \\
\text { groups }\end{array}$ & 253.34 & 2 & 126.67 & \multirow{3}{*}{181.51} & \multirow{3}{*}{$* 0.000$} \\
\hline & In groups & 27.22 & 39 & 0.70 & & \\
\hline & Total & 280.56 & 41 & & & \\
\hline \multirow{3}{*}{$\begin{array}{l}\text { Distance of } \\
\text { shot-put }\end{array}$} & $\begin{array}{l}\text { Between } \\
\text { groups }\end{array}$ & 14.15 & 2 & 7.08 & \multirow{3}{*}{37.38} & \multirow{3}{*}{$* 0.000$} \\
\hline & In groups & 7.38 & 39 & 0.19 & & \\
\hline & Total & 21.54 & 41 & & & \\
\hline
\end{tabular}

F value at $0.05=3.23$ 
Table (5) shows the results for analyzing the contrast unilateral for the stages of shot-put skill and the throwing distance in the pre measurement as well as the calculated (F) value which shows the difference for the static significant for the level 0.05 in the applied skills of shot-put and its distance, in which all the calculated values of (F) values were higher than 3.23 (F $\square 3.23)$.

Table 6. shows the results for the REGW test for choosing the contrast source in the applied skills of shot-put and its distance. Through

\begin{tabular}{|c|c|c|c|c|c|}
\hline Skill parts & Students & Average & Deviation & $\begin{array}{c}\text { Perfected } \\
\text { cooperative }\end{array}$ & $\begin{array}{l}\text { Oriented } \\
\text { Survey }\end{array}$ \\
\hline \multirow{3}{*}{ Preparation } & Traditional & 2.90 & 0.33 & $*-5.30$ & $*-5.71$ \\
\hline & $\begin{array}{l}\text { Perfected } \\
\text { cooperative }\end{array}$ & 8.20 & 0.75 & & \multirow{2}{*}{-0.41} \\
\hline & Oriented survey & 8.61 & 0.89 & & \\
\hline \multirow{3}{*}{ Crawling } & Traditional & 2.86 & 0.20 & $*-4.93$ & \multirow{3}{*}{$\begin{array}{l}*-5.07 \\
-0.14\end{array}$} \\
\hline & $\begin{array}{l}\text { Perfected } \\
\text { cooperative }\end{array}$ & 7.79 & 1.01 & & \\
\hline & Oriented survey & 7.93 & 0.89 & & \\
\hline \multirow{3}{*}{ Power situation } & Traditional & 2.88 & 0.40 & $*-4.82$ & \multirow{3}{*}{$\begin{array}{l}*-5.11 \\
-0.29\end{array}$} \\
\hline & $\begin{array}{l}\text { Perfected } \\
\text { cooperative }\end{array}$ & 7.71 & 0.98 & & \\
\hline & Oriented survey & 8.00 & 0.87 & & \\
\hline \multirow{3}{*}{$\begin{array}{l}\text { Basic accelerating } \\
\text { situation }\end{array}$} & Traditional & 2.91 & 0.32 & $*-5.05$ & \multirow{3}{*}{$\begin{array}{l}*-5.38 \\
-0.33\end{array}$} \\
\hline & $\begin{array}{l}\text { Perfected } \\
\text { cooperative }\end{array}$ & 7.96 & 0.88 & & \\
\hline & Oriented survey & 8.29 & 1.00 & & \\
\hline \multirow{3}{*}{$\begin{array}{l}\text { Hand motion } \\
\text { situation }\end{array}$} & Traditional & 2.97 & 0.22 & $*-5.36$ & \multirow{3}{*}{$\begin{array}{l}*-5.72 \\
-0.36\end{array}$} \\
\hline & $\begin{array}{l}\text { Perfected } \\
\text { cooperative }\end{array}$ & 8.33 & 1.08 & & \\
\hline & Oriented survey & 8.69 & 1.07 & & \\
\hline \multirow{3}{*}{ Covering } & Traditional & 3.06 & 0.17 & $*_{-5} 5.01$ & \multirow{3}{*}{$\begin{array}{c}*-5.38 \\
-0.37\end{array}$} \\
\hline & $\begin{array}{l}\text { Perfected } \\
\text { cooperative }\end{array}$ & 8.07 & 1.28 & & \\
\hline & Oriented survey & 8.44 & 0.65 & & \\
\hline \multirow{3}{*}{$\begin{array}{l}\text { Distance of shot- } \\
\text { put }\end{array}$} & Traditional & 6.06 & 0.31 & $*_{-1} .07$ & \multirow{3}{*}{$\begin{array}{l}*-1.34 \\
-0.27\end{array}$} \\
\hline & $\begin{array}{c}\text { Perfected } \\
\text { cooperative }\end{array}$ & 7.13 & 0.30 & & \\
\hline & Oriented survey & 7.40 & 0.62 & & \\
\hline
\end{tabular}

Table (6) shows the results for the REGW test for choosing the contrast source in the applied skills of shot-put and its distance. The results found that the difference between the traditional group and the perfected cooperative group and between the traditional group and singles oriented survey group, while there wasn't any difference with a static significant between the perfected cooperative group and the singles-oriented survey group in the applied skills or the distance of shot-put.

\section{Discussing}

According to the results of this study, the researchers found that there was a positive impact in using the perfected cooperated learning strategy on the study variables in acquiring the technical stages for effective performance of shot-put in a linear way. There was a static significant in improving those variables .

Attribute the researchers that the positive impact to the effectiveness of teaching strategy perfected cooperative learning and characterized by positive interaction and investment times of lectures fully effective and take into account individual differences among students on the one hand and the teacher on the other hand, and that can work on the access of all students to a high degree of workmanship skills for all technical stages of performance and enable students of the ability to The ability to make decisions for themselves after providing them with the necessary and required information after explaining the technical stages of the event, presentation to parts of effectiveness during the lesson, which led to increased digital achievement to the performance of the students and it is due to mastering the technical stages and their characteristics by taking into account individual differences among students and competition among them and help each other and perseverance in order to increase the degree workmanship and distinguish them from each other and their interaction outstanding with this method and the diversity of teaching methods in achieving the objectives and so that the method of the effective role and influential in the educational process in the curriculum to be implemented and that the teaching 
methods affect learning and the degree of saturation speed in learning and adaptation with the way depends on the proper understanding of, and the desired state of learning, and research and investigation This will be the role of the student to take responsibility by harnessing all the educational possibilities, educational techniques and modern teaching methods and indirect methods of assessment, and these results are consistent with the findings of both studies(Rayyan, 2005, Sabe' 1998 , Alhayek \& AL Hamoore 2005, Abo ALtayeb \& Hussien 2013)

The results related to the traditional way, confirmed that the difference for the static significant in the applied skills of shot-put as well as its distance all the differences were in favor of the post measurements. Researcher found that the traditional way had an impact on the acquisition of the technical stages in the shotput and digital achievement in the dimensional measurements, but the results of the REGW test showed that the differences were in favor of the perfected cooperative group over the traditional group This result is in agreement with the studies of ( mohammad,2000, Radi,2009).

According to the REGW test results for choosing the contrast source in the applied skills of shot-put and its distance. We found that the difference were between the traditional group in one hand and the perfected cooperative group and singles oriented survey group in the other hand. Otherwise there wasn't any difference with a static significant between the two groups; perfected cooperative and the singles-oriented survey, in the applied skills or the distance of shot- put, these results are consistent with a study (Alhamoore 2013, Alhamoore 2008 , Haidan\& Ali 2010 , Aljumaili 2002 )

The researchers found a positive and special impact of the oriented survey stratigy on the study variables in acquiring the technical stages for the effective performance of shot-put in a linear way. It provided positive interaction and it was a good investment of lectures time, taking in consideration individual differences between students through discussion and dialogue which held between the students and the teacher the thing that help them solve the prefomance problems, Hassan (1989) noted that through discussion and dialogue which held between the students and the teacher, they investigated the most appropriate way for the completion and criticism of colleagues and sensitivity to detect problems and solve them in a scientific logical way, leading them to be creative in discovering the methods and technical ways to check the level of advanced learning, guiding them to acquire scientific thinking and analytical and critical skills of the positions and the various educational missions, they had assigned to the various students who work with each other and debating among themselves, so each individual felt responsibility towards her group in order to develop the right direction towards the study and the development of skills and the ability to generate ideas to get to the good performance and constructive and valuable information to achieve their goals, the cooperative learning strategy is one of the strategies that needs to be art of leadership to reach the goals, and it is one of the influential strategies in the educational experiences, which calls for attention in the teaching-learning process, and the thrill and attention and motivation to learn, and that the students who are working in accordance with cooperative groups can understand and accommodate educational materials, better than students who are working individually and these results are consistent with (Hammouri, 2013\& Sayed,1992)studies. And the other studies in the field of science survey showed the effectiveness of the strategy, such as (Al- Ba'ajawi 2006, Al-Zghool\& Al-Mahameed, 2007)) in mathematics and study (Jaradat 2009) in mathematics and the study of ( Blanton 1988) in history and study of ( Maria 1986) in sciences.

\section{Conclusins}

In the light of the executive procedures of the current study and the results that have been reached, it is concluded the following:

1. The process of using the perfected cooperative learning strategy accelerate learning and the acquisition of motor skills and improve the level of technical performance of the stages of shot- put .

2. The process of using individual survey directed strategy accelerates the learning process and improve the level of technical performance and achievement of the effectiveness of the distance achieved with the shotput.

3 - The process of using perfected cooperative learning strategy helps achieve distance in the shot- put games for the study sample.

4.The process of using the perfected cooperative learning strategy saves a lot of time and effort and the ability to acquire practical skills among the sample of the study.

5-The process using perfected cooperative learning strategy raises the students thinking and accepting teamwork among students of cooperation and help each other and overcome them in all educational learning situations in groups.

6 - The process of using individual survey orientated strategy raises the students thinking and acceptance of individual work between students by researching and investigating to find the best solution to solve the problems and to answer questions posed to students by the teacher.

\section{Recommendations and proposals}

It is recommended to use the perfected cooperative learning strategy based on the directed individual survey strategy program in different physical education courses for its value in improving the level of technical performance. 


\section{References}

Abu Al- Tayeb, M \& Hussein, A(2013). The impact of teaching on the discovery oriented innovative thinking and some basic swimming skills for children from (5-6) years, release (3), 502-540.

Al-Ba'ajawi, A (2006)."The impact of individual and collaborative survey directed and survey to acquire communication skills and achievement in mathematics among students in the intermediate stage basic strategy for Jordan", Unpublished doctoral dissertation, Amman Arab University for Graduate Studies.

Al-Hamoory, W (2013),"Cooperative building based on the survey-oriented strategy statement and its impact on the educational program to improve the life skills and creative thinking skills, and improve the level of performance for the students studying athletics in the university of jordan."Al-Oloum Ah-Islamieh Al-Alermiauniversity, published doctoral dissertation.

Al-Hamoory, W (2008). Compared to the impact of computer use and application under the guidance peers in the education of skill extrusion the disk, First International Conference of Physical Education and Sports and Health, Kuwait, the first volume of scientific research study (1) Search No (5) 1-4/4/2008

Al-Hayek, S \& Hamory. W (2005). The degree of preference for sports students to teaching methods used in teaching basketball curricula, and directions to it, - Bahrain: Journal of Educational and Psychological Science, vol (6) (3). Page 200.

Al-Hilah, M (1999).Instructional Design and practice. T 1 distributed and published in Amman Dar El-Ser. Page 329.

Al-jumaili, B (2002). The impact of perfected learning in the acquisition and retention of some basic volleyball skills, doctoral dissertation Baghdad University- physical education collage, published.

Al-Zghool, E \& Al-Mahameed, S (2007). The psychology of classroom teachin, Amman: Dar Al-Masira for distributing and publishing.

Asamady, M (2007), Teaching between theory and practice strategy, Amman: Dar Al-qendeel for distributing and publishing.

Hassan, O (1989). "Measuring the degree to which the College of Education Department of Arabic language students to understand and use the tools necessary to link them" Masters letter, unpublished, Assiut University.

Haidan, H \& Ali , A (2010). The effect of using perfected learning style to learn the skill of handling and transfer the track to the skill of the getting a point in the hand ball, Journal of Physical Education Science, No. 4, Volume 3 page 231-247.

Jaradat, H (2009). "The effect of using the collaborative survey strategy and individual survey in the teaching of the possibilities in mathematical achievement and probabilistic thinking for higher primary school students in Jordan" Unpublished doctoral dissertation, Amman Arab University for Graduate Studies.

Maria, C. (1986). An Evaluation of the Effectiveness of the Use of Inquiry Instruction to Foster Creativity in Intermediate Grade Student. DAI, 42(2), 642-A.

Mohammad, D (2000). The impact of the use of certain teaching styles on learning disk competition, PHD letter, unpublished, physical education collage, Tanta University.

Mosston M. \& Ashworth, S.(1986). Teaching physical Education (therid). Merrill publishing Company. Columbus, Ohio.

Radi, E (2009), The impact for the use of style perfected learning and cooperative learning in some offensive skills composite basketball,Basic Education collage/ Al-Mustanseria University, Journal of Basic Education College, Number 56.

Rayyan, M (2005). Cooperative learning for the development of creative thinking strategy, Copy 1.

Sabea', A(1998)perfected learning by using the methods of training and accumulated under the distributor training system and conditions and different effort, published doctoral dissertation, physical education collage, Baghdad .

Salavin, R (2005). Cooperative learning student Achievement Educational Leadership ,46(2) : 31 -33.

Sayed, Fatima(1992). "The effect of using the teaching method of the survey on the collection and retention of grade elaven Chemistry students". Unpublished Masters letter, collage of education, Al-Madina AlMunawara, King Abd Al-Aziz University, Saudi Arabia. 